\title{
Krisiak etxegabetasunean izandako eragina: esku-hartze soziala, beharrizan gehiago eta baliabide gutxiago daudenean
}

\author{
Xabier Aierdi Urraza \\ Euskal Herriko Unibertsitatea (UPV/EHU) \\ <xabier.aierdi@ehu.es>
}

\author{
Gorka Moreno Márquez \\ Euskal Herriko Unibertsitatea (UPV/EHU) \\ <gorka.moreno@ehu.es>
}

\begin{abstract}
Artikulu honetan sakonago aztertu nahi da krisi ekonomiko eta soziala Espainiako etxerik gabeko pertsonengan izaten ari den eragina. Horretarako, krisiaren aurretiko unean egindako ikerketa baten emaitzak aurkeztuko dira, baita atzeraldi ekonomiko bete-betean egindako eguneratzearenak ere. $\mathrm{Bi}$ uneetako emaitza nagusien bilakaera aurkeztuko da. Krisiaren ondorioz etxerik gabeko pertsonen kopuruak gora egin duela ikusten da. Halaber, kolektiboaren ezaugarri batzuk mantentzen diren arren, beste batzuk aldatu egin dira. Lanmerkatura sartzeko zailtasunen eta zenbait prestazio ekonomikoren murrizketen ondorioz, luzatzen ari da gizarteratze-prozesuen iraupena. Testuinguru horretan, etxerik gabeko pertsonen egoera pertsonala ere okerragotzen ari da, batez ere buru-patologiei eta kontsumoei dagokienez. Immigranteen kolektiboa ari da eragin hori larritasun handienez jasaten.
\end{abstract}

\section{HITZAK-GAKOAK:}

etxegabetasuna, krisi ekonomikoa, gizartebazterketa, gizarte-zerbitzuak, Espaina.
En este artículo se pretende profundizar en el impacto que está teniendo la crisis económica y social sobre las personas sin hogar en España. Para ello, se presentan los resultados de una investigación realizada en el momento previo a la crisis y su actualización en pleno periodo de recesión económica, destacando los principales resultados en ambas en clave evolutiva. Como consecuencia de la crisis se detecta un aumento del número de personas sin hogar. Igualmente, y aunque se mantienen algunas características del colectivo, otras se han modificado. Así, las dificultades de acceso al mercado laboral y el recorte en ciertas prestaciones económicas están haciendo que la duración de los procesos de incorporación social aumente. Este contexto está haciendo que la situación personal de las personas sin hogar también empeore, sobre todo en aspectos como las patologías mentales 0 los consumos. El colectivo inmigrante es el que más intensamente está sufriendo este impacto.

\section{Palabras Clave:}

sinhogarismo, crisis económica, exclusión social, servicios sociales, España. 


\section{Sarrera}

Mundu-mailako krisi ekonomikoaren eragina larrienik jasaten ari den herrialdeetako bat da Espainia. Besteak beste, azken urteotan nabarmen hazi diren gizarte-bazterketan eta txirotasunean ari dira izaten ondorioak. Etxegabetasuna, gizarte-bazterketaren muturreko kategoria izanik, ez da salbuespena, eta krisi ekonomikoaren bultzaldiak jasaten ari da.

Krisi honek etxerik gabeko pertsonengan duen eragina aztertuko dugu artikulu honen bidez. Horretarako, krisiaren aurretik egindako ikerketa baten emaitza nagusiak aurkeztuko ditugu, baita krisi larriko eta atzeraldi ekonomikoko ondorengo une batean egindako eguneratzearenak ere. Hala, gertakariaren luzetarako analisia egin daiteke, kolektiboaren barruko jarraitutasunak, aldaketak eta beharrizanak nabarmenduta. Zehazki esanda, hiru alderdi nabarmenduko dira: kolektiboko pertsonen kopurua eta ezaugarriak, dituzten beharrizanak eta erakundeek gertakariari emandako erantzuna.

Ikerketaren egiturari dagokionez, lehenengo atalean, etxegabetasunari buruzko eduki eta kontzeptu nagusien berrikuste bibliografikoa egingo dugu, baita hari buruz Espainian egindako azterketena ere; lanik aipagarrienak eta gertakariaren neurketa azpimarratuko ditugu.

Ondoren, arestian aipatutako bi ikerketen emaitza nagusiak aurkeztuko ditugu. Hasieran, krisiaren aurreko aldiarekin lotura duten alderdi nagusiak adieraziko dira; besteak beste, kolektiboko pertsonen kopurua eta ezaugarriak, dituzten beharrizanak eta une hartan ematen zitzaien arreta. Ondoren, krisiaren eraginera eta horrek etxegabetasunean sortu dituen aldaketetara bideratuko dugu artikulua. Aldaketa horiek alderatuz aztertuko ditugu, krisiaren aurretiko garaiarekiko jarraitutasunak eta, batez ere, hausturak nabarmentzeko.

Artikulua amaitzeko, emaitzetatik ateratako ondorio nagusien laburpena egingo dugu. Etxerik gabeko pertsonen kolektiboan krisiak eragindako ondorioei buruz hausnartuko dugu, baita etorkizunari begira epe laburrean eta ertainean ikus daitezkeen aukerei buruz ere; beti ere, etxerik gabeko pertsonen esku-hartze sozialarekin eta arretarekin lotura duten alderdi asko berriz aztertu eta berriz hausnartu beharra dagoela azpimarratuta.

\section{Etxegabetasunaren azterketa}

Gizarte-bazterketaren barruan etxegabetasuna da, beharbada, egoerarik muturrekoena; gizarte-zientzietan, behintzat, gero eta garrantzi handiagoa hartzen ari da gertakari hori. Herrialde anglosaxoietan, batez ere Estatu Batuetan, duela hamarkada batzuetatik hona ari dira etxegabetasuna aztertzen, eta garapen akademiko handiagoa izan du (Philippot et al., 2007; Meanwell, 2012). Horrela, herrialde hartan 8oko hamarkadaren amaieran hartu bazuen ere arlo horrek indarra (Rossi, 1989; Jencks, 1994), Europan ez zen garatu goeko hamarkadaren amaiera arte (Toro, 2007).

Desberdintasunak ez dira soilik denboraren esparrukoak, baita hurbilketa teorikoari edota sozialari dagozkionak ere. Estatu Batuen kasuan, gizabanakoaren alderdiak eta banakako arazoak nabarmentzen dira; Europakoan, berriz, gizartearen eta egituraren aldetik aztertzen da etxegabetasuna (Cohen, 1995; Hombs, 2001; Tompset et al., 2003; Toro, 2007). Ongizate-ereduetan eta horien garapenetan ere aldeak daude, eta eragina dute etxerik gabeko pertsonengana egiten den hurbilketan eta esku-hartzean (Shinn, 2007; O’Sullivan, 2010).

Europan, etxegabetasunaren azterketa garrantzitsua egiten ari da FEANTSA ${ }^{1}$ (European Federation of National Organisations working with the Homeless) 1989az geroztik; gobernuz kanpoko erakunde horrek etxegabetasunaren esparruan lan egiten duten gizarteerakundeak biltzen ditu. Hain zuzen ere, 2010. urtea Txirotasunaren eta Gizarte Bazterketaren Aurkako Borrokaren Europako Urtea zela baliatuta, federazio horrek abian jarri zuen 2015erako kaleko etxegabetasuna -gertakari horren egoerarik larriena- erauzteko kanpaina. Horren ondorioz, Europako Parlamentuak adierazpen instituzionala egin zuen ildo horri jarraiki. Eta berriki, adierazpen hori arloari buruzko irizpen komunitario bilakatu da (Europar Batasuna, 2012), eta bertan, arazoari aurre egiteko zenbait gomendio biltzen dira; besteak beste, etxebizitza-politikak sendotzea, esparru horri diru-kopuru handiagoa ematea, eta abian jartzea etxerik gabeko pertsonen Europako Agentzia.

Kontzeptuari dagokionez, zaila da herrialde eta ikerketa guztietan definizio bakarra eta bateratua aurkitzea (Brousse, 2004; Busch-Geertsema, 2010). Hori dela eta, askotan zaila izaten da gertakaria aztertzea eta herrialdeen arteko alderaketak egitea (Edgar, Doherty eta Meert, 2002; Europako Batzordea, 2007; Edgar eta Doherty, 2010).

Dena den, Europan gehien erabiltzen den definizioa FEANTSAk duela urte batzuk emandakoa da; ETHOS izeneko definizio horrek etxegabetasunaren barruan dauden intentsitate desberdineko kategoriak eta egoerak biltzen ditu. Hain zuzen ere, lau kategoria zehazten ditu -roofless, houseless, insecure housing eta inadequate housing-, eta horien barruan hamahiru bizigarritasun-egoera: egoera larrienetik hasi, kalean bizitzea litzatekeena, eta egoera moderatuagoetara, baldintza txarretako etxeetan edo pilatuta bizitzea (Edgar, Doherty eta Meert, 2004; Edgar eta Meert, 2005; Edgar, 2009).

Ikerketa-motari dagokionez, kolektiboaren ezaugarriekin eta zenbaketarekin lotutako alderdietan

${ }^{1}$ Federazio honek Europa mailan egiten du lan, eta bere helburuak dira Europar Batasunaren politika publikoetan eragina izatea eta hura osatzen duten erakundeen artean koordinazioa sustatzea. Modu berean, txostenak eta ikerketak egiten ditu etxegabetasunaren esparruan, eta gaiarekin erlazionatutako hainbat material argitaratzen ditu. Sakontzeko, joan hona: 〈http://www.feantsa.org〉. 
jartzen dute arreta eta, besteak beste, kolektiboaren profilak eta bereizgarriak nabarmentzen dituzte. Lan horietako gehienak joera zenbatzaileko azterketen eta metodologien bidez egiten dira, inkestak, batez ere (Appelbaum, 1990; Koegel, Burnam eta Morton, 1996; Toro et al., 1999; Firdion eta Marpsat, 2007). Baina baita beste iturri-mota batzuk ere, hala nola, erregistroak eta hiri handietako kale-kontaketak (Cabrera, 2009).

Azterketa-elementu garrantzitsua izan da, eta da, kolektiboaren zenbaketa, eta bere ezaugarriekin eta definizioarekin lotura duten zailtasun batzuk sorrarazi ditu (Avramov, 2002; Busch-Geertsema, 2010; Williams, 2011). Europa mailan, adibidez, hainbat definizio eta metodologia daude herrialdearen arabera (FEANTSA, 2012b; European Observatory on Homelessness, 2012). Avramov-en (1996) estimazioen arabera, 1996an 2,7 milioi pertsona inguru zeuden etxegabetasun-egoeran EB-15ean. Estatu Batuetan, datu berriagoekin, 645.000 pertsona dira (Byrne et al., 2012). Hala ere, nabarmendu behar da, arestian esan den moduan, kolektiboaren definizioak baldintzatzen duela amaierako zenbatekoa.

Etxegabetasunaren azterketaren gainbegiratu orokor hau amaitzeko, aipatu behar da gaiaren barruan arreta gehien pizten duten ezaugarrien edo kolektiboen artean daudela, besteak beste, etxerik gabeko gazteak (Avramov, 1998; Quilgars, 2010) eta etxerik gabeko emakumeak (Burt eta Cohen, 1989; Passaro, 1996; Vostanis et al., 2001; Pippert, 2007; Jasinski et al., 2010). Azken urteetan garrantzia hartu du (im)migratzaileen kolektiboaren analisiak, bai Europa mailan (Mayock, Sheridan eta Parker, 2012), bai Espainia mailan (Cabrera eta Malgesini, 2002; Cabrera, 2007; Bosch, 2010). Hain zuzen ere, kolektibo hori dela uste da krisiaren eragina larrien jasaten ari denetako bat (FEANTSA, 2011, 2012b).

Nazioartea albo batera utzi eta arreta Espainian jarrita, ikus daiteke etxegabetasuna goeko hamarkadaren erdialdetik eta amaieratik aztertzen ari direla (Muñoz eta Vázquez, 1999; Vazquez et al., 2003; Cabrera, 2004; Cabrera, Rubio eta Blasco, 2008). Egindako azterketen artean nabarmendu behar dira hainbat inkesta eta zenbaketa-joera duten zenbait lan; gehienek azpimarratzen dute gizonak emakumeak baino gehiago direla, kolektiboa nahiko gaztea dela, eta etengabe hazten ari dela etxerik gabeko atzerritarren kopurua (Rico, Vega eta Aranguren, 1994; Muñoz, Vázquez eta Cruzado, 1995).

Estatistika-erakunde ofizialek ere egiten dituzte mota horretako inkestak. Adibidez, Espainiako Estatistika Institutuak (INE) badauka etxerik gabeko pertsonen inkesta bat. 2005ean etxerik gabeko pertsonei egindako inkestako datuen arabera, Espainian etxerik gabeko 22.000 pertsona inguruk jotzen zuten baliabide-motaren baten bila (INE, 2005). Duela gutxi, inkesta berberaren, 2012ko edizioaren, datuen aurrerapena aurkeztu da. Lehenengo datuen artean azpimarratu behar da etxerik gabeko 22.938 pertsona daudela Espainia osoan, 2005ean baino \% 4,5 gehiago; baina kolektiboaren definizioa zabala da, eta bere baitan hartzen ditu, adibidez, barneratzezentroak eta emakumeentzako harrera-zentroak. Nabarmendu behar da ez dituela kontuan hartzen inolako gizarte-baliabideren bila jotzen ez duten etxerik gabeko pertsonak. Euskadin, artikulu honek aztertzen duen lurraldean, hazkunde hori \% 14,5ekoa da 2005 arekiko.

Inkestekin batera, azken urteetan, Espainian garrantzia hartu dute hiri handietan egindako kalezenbaketa bidezko etxegabetasunaren azterketek. Besteak beste, Austrian, Belgikan, Ingalaterran, Alemanian, Hungarian, Irlandan, Holandan eta Portugalen erabiltzen ari den teknika hori (Busch-Geertsema, 2010) ari dira erabiltzen Espainiako hirietan ere, hala nola, Madrilen (Cabrera, 2006), Bartzelonan (Cabrera, Rubio eta Blasco, 2008) eta Bilbon (Bilboko Udala, 2011).

\section{Metodologia}

Artikulu honen bidez, izaera kualitatiboa eta luzetarakoa dituen hurbilketa egingo dugu krisiaren eraginera. Horretarako, Euskadiri buruzko azterketa bat analizatuko dugu. Azterketa horrek berezitasunen bat izan badezake ere, emaitza gehienak Espainia osora estrapola daitezke. Horrela, une desberdinetan egindako bi azterketen emaitzak analizatuko ditugu.

Lehena 2008. urtearen hasieran egin zen -krisi ekonomikoaren aurretiko edo hasierako aldia-, eta etxerik gabeko pertsonen ezaugarriak, profilak eta beharrizanak analizatzea zuen helburu. Horretarako, elkarrizketa sakonak egin zitzaizkien gai honetan adituak diren 17 pertsonari, eta elkarrizketak etxerik gabeko 33 pertsonari; horrez gain, bi eztabaidatalde ere egin ziren. Etxerik gabeko pertsonentzako galdera-sorta bat ere prestatu zen, eta 200 pertsonak baino gehiagok erantzun zuten.

Bigarren ikerketa 2012. urtearen erdialdera egin zen, eta aurreko ikerketaren ondorio nagusiak eguneratzea zuen helburu, krisiaren eragina ikusi ahal izateko. Ikerketa horretan, elkarrizketa sakonak egin zitzaizkien gai honetan adituak diren 13 pertsonari; baita bi eztabaida-talde ere.

Analizatutako informazio gehiena elkarrizketa sakonetan eta eztabaida-taldeetan oinarritua dago, eta arreta berezia jartzen da 2012an egindako azterketan. Beraz, joera kualitatiboa duen hurbilketa nagusitzen da, etxegabetasunaren arloan; Europan herrialde anglosaxoietan baino gehiago landu da hori (Toro, 2007). Nabarmendu behar da, azken urteetan Estatu Batuetan luzetarako ikuspegiak nolabaiteko garrantzia hartu badu ere (Shinn et al., 1998; Zlotnick, Robertson eta Lahiff, 1999; Warnes eta Crane, 2006; Toro, Dworsky eta Fowler, 2007), arlo horretan, Europa mailan, oso lan gutxi egin direla, eta are gutxiago krisiaren eragina konparazio bidez neurtzeko helburua dutenak. 


\section{Emaitzak}

\subsection{Etxegabetasuna krisiaren aurretik}

Bizkaian, krisi ekonomikoaren aurretiko aldian uste zen 250-26o pertsona inguruk igarotzen zutela gaua etxerik gabe edo kalean dauden pertsonentzat egokitutako baliabideetan. Arestian adierazi den moduan, kolektiboaren definizioak zeresan handia du zenbatekoa zehaztean; kasu horretan definizio oso mugatua aukeratu zen, ETHOS sailkapeneko kategoria baxuenak soilik jasotzen baitzituen: gaua kalean ematen duten pertsonak (people living rough) eta gaua igarotzeko prestatutako baliabideren batean gaua ematen dutenak (people staying in a night shelter).

Kolektiboaren ezaugarri garrantzitsuenetako bat da etxerik gabeko pertsonen gehiengoa gizonak direla: \% 91,5 gizonak eta \% 8,5 emakumeak. Zifra horiek bat datoz Espainia mailan arlo honetan egindako beste azterketa batzuekin. Europa mailan azpimarratu behar da, gizonak oraindik gehiengoa badira ere, gero eta emakume gehiago daudela kolektiboan. Adibide bat emate aldera, Frantzian, 9oeko hamarkadaren amaieran, etxerik gabeko emakumeak 25 urtetik azpiko pertsonen \% 37 ziren (Meert et al., 2005: 12). Batez besteko adina 36 urte da: $\% 30$ ak 30 urtetik behera ditu, \% 31k 30 eta 39 urte artean, eta \% 39 dira 40 urtetik gorakoak. Beraz, populazio oso gaztea da eta \% 6otik gora dira 40 urtetik beherakoak.

Aipatu beharreko beste datu bat da atzerritarrak gehiengoa direla, gutxigatik bada ere, $\% 52,5$. Egiaztatu egiten da, beraz, Espainiako hiri nagusietan azkeneko urteetan izaten ari den joera, hau da, immigranteen populazioa hazten ari dela etxerik gabeko pertsonen artean (INE, 2005; EUSTAT, 2005), eta etxerik gabekoen populazioaren erdia inguru osatzen dutela (Rodríguez García, 2008). Populazio atzerritarraren gehiengoa (\% 59) magrebtarra da, eta horien barruan marokoarrak dira gehienak; hain zuzen ere, etxerik gabeko atzerritarren populazio osoaren \% 44 dira. Gainera, etxerik gabeko immigranteen populazioaren gaztetasuna azpimarratu behar da: \% 45,7k 30 urtetik behera ditu. Aldiz, etxerik gabeko bertako populazioaren $\% 12,6$ soilik da adin horretatik beherakoa. Hau da, etxerik gabeko populazio atzerritarraren profila askoz gazteagoa da atzerritarren profila baino.

Beraz, bi profil edo talde handi bereizten dira etxerik gabekoen kolektiboan:

- Lehenengoa etxerik gabeko pertsonaren profil tradizionala da: pasadizokoa, osasun aldetik oso hondatua eta arazo pertsonalak dituena, droga- eta alkohol-kontsumoarekin eta burugaixotasunekin lotura dutenak. Kasu horretan, etxebizitza aldetik bazterketa-egoeran egoteaz gain, gizarte-bazterketa areagotzen duten arazo pertsonalak gehitzen zaizkio (Burt, 2001; Hwang, 2001; Wolitski, Kider eta Fenton, 2007; Ellen eta O'Flaherty, 2010). Talde hori bertako pertsonek osatzen dute, ia erabat.
- Bigarrengoak profil berriagoa du: osatzen duten pertsonen gaztetasuna eta osasun ona nabarmentzen dira. Profil honetan, krisiaren aurretik, etxebizitza-bazterketa soilik antzematen zen, baina ez arlo pertsonaleko arazorik. Bigarren profil horretan etxerik gabeko atzerritarrak daude, batez ere gazteenak eta magrebtarrak.

1. taulak irudikatzen ditu bi profil horiek; horrela, arazo pertsonalak -mendekotasunak, buru-gaixotasunak, osasun-egoera txarra- dituzten pertsonak $\%$ 38,1 dira atzerritarren artean, eta \% 88,4 bertakoen artean. Era berean, soilik etxebizitzaren aldetik bazterketa-arazoa dutenak \% 61,9 dira atzerritarren artean, eta \% 11,6 bertakoen artean.

1. taula. Etxerik gabeko bertako eta atzerriko pertsonak, egoera pertsonalaren arabera

\begin{tabular}{l|c|c|c|c|c|c}
\cline { 2 - 7 } & \multicolumn{2}{c|}{ Bertakoak } & \multicolumn{2}{c|}{ Etorkinak } & \multicolumn{2}{c}{ Guztira } \\
\cline { 2 - 7 } & $\mathbf{N}$ & $\%$ & $\mathbf{N}$ & $\%$ & $\mathbf{N}$ & $\%$ \\
\hline $\begin{array}{l}\text { Norberaren } \\
\text { arazoak gehi } \\
\text { alojamendu } \\
\text { falta }\end{array}$ & 84 & 88,4 & 40 & 38,1 & 124 & 62,0 \\
\hline $\begin{array}{l}\text { Soilik } \\
\text { alojamendu } \\
\text { falta }\end{array}$ & 11 & 11,6 & 65 & 61,9 & 76 & 38,0 \\
\hline Guztira & 95 & 100,0 & 105 & 100,0 & 200 & 100,0 \\
\hline
\end{tabular}

Iturria: Egileen lana.

Ezaugarri horiek erakusten dute desberdinak direla batzuen eta besteen bizitza-ibilbideak eta beharrizanak, are kontrakoak. Horrela, etxerik gabeko pertsonentzat gizarte-baliabideak 'azken babes-sare' bihurtzen dira; etxerik gabeko atzerritar gehienentzat, berriz, berek 'gizarteratzeko tranpolin' gisa balio dezakete baliabide horiek, batez ere gazteentzat (Moreno eta Aierdi, 2008). Azken finean, anormalizatu egin ziren krisiaren aurretik ostatu hartzeko lekurik ez zuten eta gizarte-bazterketari datxekion beste baldintzarik ere ez zuten pertsonen egoerak.

\subsection{Krisiaren eragina etxerik gabeko pertsonengan}

\subsubsection{Etxegabetasunaren analisia krisi ekonomikoaren garaian}

Orain arte ez da ikerketa handirik egin krisi ekonomikoak etxegabetasunean izandako eraginari buruz. Europa mailan zenbait saiakera nabarmendu behar dira; besteak beste, FEANTSAk 2009an Bruselan antolatutako europar mintegia. Han, gaiari buruzko alderdiak aztertu ziren, eta krisi ekonomikoko eta gizarte-politiken murrizketen aldian etxegabetasunari aurre egiteko moduak landu ziren.

Nabarmentzekoa da, baita ere, oraindik krisiaren eraginari buruz azterketa aplikatu garrantzitsurik ez badago ere, datu estatistiko gehienek adierazten 
dutenaren arabera, atzeraldi ekonomikoko azken urteotan hazi egin dela etxerik gabeko pertsonen kopurua (Frazer eta Marlier, 2011; FEANTSA, 2012a). Hazkunde hori, besteak beste, Erresuma Batuan (UK Local Gobernment Association, 2008) eta Estatu Batuetan (Markee, 2009) ari da gertatzen. Europako kasuan, batez ere, krisi-egoera larrienean dauden herrialdeetan antzematen da (Murphy, 2011), besteak beste, Grezian, Portugalen eta Espainian bertan. Horietan, hazkundea \% 25-30 ingurukoa dela uste da (FEANTSA, 2012b: 21).

Beharbada Greziaren kasua da ezagunena, bere mugak gainditu baititu eta Espainiako komunikabide orokorrek ere herrialde horretako egoeraren berri eman baitute. Horrela, Atenasen lan egiten duten zenbait gizarte-erakunderen esanetan, hiri horretan, etxerik gabeko pertsonen kopurua \% 25 hazi da azken bizpahiru urteotan, guztira etxerik gabeko 20.000 pertsona izatera iritsi arte (Mars, 2012). Etxerik gabeko populazioaren hazkunde hori gizartebazterketaren eta etxegabetasunaren aurka bideratutako aurrekontuen murrizketarekin batera gertatu da (Anderson, 2010; FEANTSA, 2011).

Espainiako kasuan, 2012an INEk etxerik gabeko pertsonei egindako inkestaren eguneratzeaz gain, ez dago krisiak etxegabetasunean izandako eragina aztertzen duen azterketa garrantzitsurik, eta krisiak gizarte-bazterketako egoeran dauden pertsonengan eragindako efektuetan jartzen dute arreta ikerketa gehienek (Laparra eta Pérez, 2010; Fundación FOESSA, 2012). Halaber, etxegabetasunari buruzko hainbat datu aurki daitezke kolektibo horrekin lan egiten duten gizarte-erakundeen erregistroen eta txostenen bitartez. Hala, Caritasen arabera, krisiaren lehenengo urteetan -2007tik 2008ra- etxerik gabeko pertsonen kopurua \% 21 hazi zen Espainian (Cáritas, 2009).

\subsubsection{Aldaketak etxerik gabeko pertsonen bolumenean, profiletan eta beharrizanetan}

Ondorioz, etxerik gabeko pertsonen kopurua hazi egin dela antzematen da aztertutako geografiaeremuan. Etxerik gabeko pertsonen kopuru zehatz samarra ematea zaila den arren, kontsultatutako pertsonak bat etorri dira 400-430 inguruko zifra ematean; krisiaren aurretik 250-260 inguru ziren. Kontuan izanik, igarotako aldian, gizarte-laguntzako baliabideen kopurua ez dela asko hazi, badirudi pertsona berri horien gehiengoak kalean edo 'ezohiko ostatuetan' (utzitako pabiloi industrialak, etxe okupatuak edo antzekoak) pasatzen duela gaua.

Etxerik gabeko pertsonen kopurua haztearen arrazoi nagusia da egoera horretan jada egondako pertsonak lehengo egoerara erori direla, atzera egin dutela gizarteratze-prozesuan. Beraz, ez dirudi berresten denik krisiaren aurretik integratuta zeuden pertsonak krisiaren ondorioz muturreko egoeretara iristen ari direla dioen hipotesia. Zentzu horretan, badirudi egiaztatu egiten dela gizarte- eta familia-sarearen bidez lortu egiten dela gizarte-bazterketa larrienak ekiditea eta haiei aurre egitea (Laparra eta Pérez, 2010; Cáritas, 2012). Nabarmentzekoa da, itxura batean, mantentzen ari dela bertako eta atzerriko pertsonen kopurua, baita ezaugarri soziodemografiko gehienak ere -adina, sexua eta abar-.

Horrela, etxerik gabeko pertsonen kopurua hazteaz gain, aldaketa nagusiak maila kualitatiboan eta gizarteratze-prozesuen ibilbideetan ari dira gertatzen. Hala, etxerik gabeko atzerritarren artean gero eta gehiago dira izaera indibidualeko arazoak dituztenak, batez ere, buru-patologiekin lotura dutenak eta, gutxiago, kontsumoekin zerikusia dutenak.

Horrek krisiaren aurreko aldiko joera hausten du, eta, itxura batean, krisia kolektibo honi kalte egiten ari zaiola adierazten du, batez ere, gizarteratze-prozesu luzeago eta zailagoek eragiten duten frustrazioa haztearen ondorioz. Krisiaren aurretik, lana -eskasazen kolektibo horren gizarteratze-prozesuen azken maila, batez ere, arazo pertsonal handirik ez zuten etxerik gabeko atzerritarrentzat; eta lan hori integraziorako tranpolin antzeko bihurtzen zen. Gaur egun, 'palanka' hori ia guztiz desagertu da; gizarteratzeprozesuak kroniko bihurtzen dira, eta prestakuntzatik lan-merkatura igarotzea oso traumatiko bihurtzen da kasurik gehienetan.

Gizarteratze-prozesuak gehiago luzarazi dituzte azken hilabeteotan zenbait gizarte-zerbitzutan izandako murrizketek, besteak beste, etxerik gabeko pertsonen sektore batzuetara iristen zen Diru-sarrerak Bermatzeko Errentan izandakoak -gutxieneko errenten programa-. Lege-aldaketek -urtebeteren ordez hiru urtez erroldatuta egon beharra-zaildu egin dute laguntza horiek lortzea, batez ere immigranteen kolektiboarentzat.

Laburbilduz, lan-egoerak eta zenbait laguntzetan izandako murrizketek askoz konplikatuago bihurtu dute urgentziazko baliabideetatik normalizatuetara igarotzea, batez ere atzerritarren artean. Arazo pertsonalik ez zuten pertsonentzat igarotze hori nahiko erraza eta automatikoa zen krisiaren aurreko aldian. Horrek guztiak eragin ditu pertsona horien buruosasuna okertzea eta frustrazioa haztea; horrek, azkenean, arazo pertsonalak hedatzea dakar, eta ondorioz, zaildu egiten dira gizarteratze-prozesua eta integraziorako jauzia, eta denboran luzatu.

\section{Ondorioak eta eztabaida}

Amaitzeko, eta artikuluaren laburpen gisa, nabarmendu behar da etxerik gabeko pertsonen ezaugarri eta beharrizan gehienak ez direla aldatu krisiarekin, eta berberak direla aldi batean zein bestean.

Hala ere, krisi ekonomikoari oso lotuta dauden aldaketa batzuk antzematen dira, eta horiek eragina dute bai kolektiboaren gizarteratze-prozesuetan, bai egoera pertsonalean. Lan-merkatuaren ahultasunak desagerrarazi egin du goranzko gizarteratzeprozesuen azkeneko katebegia -lana- etxerik gabeko 
pertsona gehienentzat, batez ere, egoera hobean zeuden eta soldatapeko lan bat nahiko normal lor zezaketen haientzat, nahiz eta lan hori eskasa izan. Gizartelaguntzetan azkenaldian izan diren murrizketen ondorioz, oso zail edo ezinezko bilakatu da laguntza horiek lortzea etxerik gabeko zenbait pertsonentzat; sarritan, ezinbesteko elementua ziren gizarteratzeprozesurako, ahultasun-egoerak ez ugaritzeko eta gizarte-bazterketa larrienera erortzea ekiditeko.

Bi faktore horien eraginez gizarteratze-prozesuen iraupena luzeagoa eta zailagoa da eta, batez ere, krisiaren aurreko ikerketan antzeman zen profiletako bati eragiten dio, etxebizitza-bazterketari dagozkion arazoak soilik zituzten atzerritarrenari. Kolektibo horretan antzematen da gehiagok dituztela banakako arazoak eta ez ostatuaren beharrari soilik lotutakoek.

Beste era batean esanda, krisiaren aurreko aldian etxegabetasunaren arretarako baliabideak 'gizarteratzeko lehenengo tranpolina' ziren etxerik gabeko atzerritarrarentzat -batez ere iritsi berrientzat-. Gaur egun, gizarte-bazterketa larrienera erakartzen dituen izugarrizko ‘armiarma-sare’ bihurtu dira, eta, gainera, ez die aurrera egiten uzten.

Testuinguru horretan, gizarteratzeko aukerak izugarri korapilatu ziren etxerik gabeko immigranteen kolektiboarentzat; gizarte- eta familia-sare txikiagoa zutenez, muturreko gizarte-bazterketa iraunkorrera eraman zituen praktikan (O'Connel, 2004; Wright eta Tompkins, 2005).

Modu berean, testuinguru honek erronka handiak ditu, bai arlo honetan lan egiten duten profesionalentzat, bai gizarte-babes osoarentzat. Are gehiago, kontuan izanda egoera ekonomikoak erabat baldintzatzen duela gaur egun eraikitzen ari den egoera. Beste modu batean esanda, badirudi etxerik gabeko pertsonen arretan 'gehiago gutxiagogatik' egoera sortzen ari dela: zailtasun eta zeregin gehiago baliabide gutxiagoko testuinguruan, hau da, gizarteratzea zailagoa eta konplexuagoa, eta aldi berean, baliabide ekonomikoak urriagoak.

\begin{tabular}{|l|l|}
\hline \multicolumn{2}{|l|}{ 1. koadroa. Krisiaren eragina etxegabetasunaren egoeran } \\
\hline Testuinguru sozioekonomikoa & $\begin{array}{l}\text { Egoeraren aldaketa eta } \\
\text { okerragotzea. }\end{array}$ \\
\hline $\begin{array}{l}\text { Kuantifikazioa eta } \\
\text { kolektiboaren ezaugarriak }\end{array}$ & $\begin{array}{l}\text { Jarraikortasunak eta aldaketa } \\
\text { kualitatiboak. }\end{array}$ \\
\hline Kolektiboaren beharrak & $\begin{array}{l}\text { Jarraikortasunak eta egoeraren } \\
\text { okerragotzea. }\end{array}$ \\
\hline Erantzun mota & $\begin{array}{l}\text { Konplexua eta anitza. } \\
\text { Aldaketaren beharra. }\end{array}$ \\
\hline
\end{tabular}

Iturria: Egileen lana.

Egoera horrek hausnarketa sakona eskatzen du, nahi eta nahi ez, etxegabetasunaren esparruan eta arlo horretan ekiteko eta esku hartzeko moduan. Arretaren eta baliabideen malgutasun eta aniztasun handiagoa eragingo dituen aldaketa (Daiski, 2007; Elissen et al., 2013), eta profesionala erabiltzailearen beharrizanetara moldatzea bilatuko duena, ez alderantziz (Baptista, 2010; Benjaminsen eta Dyb, 2010); izan ere, baliabide handietan oinarritutako ereduak bideraezina dirudi gaur egun. Hasiera batean, urruneko geltokia dirudi, baina arlo honetako zenbait erakunderen eta profesionalen artean hasi dira antzematen kezka horiek, baita krisiaren aurretiko urteetan egiten zen esku-hartzearen aldean desberdina izango den beste bat proposatzeko beharra ere.

Azken finean, ziurtasunik ezak eta egoeraren balorazioan alderdi negatiboek indarra hartzen duten egoera ari da gailentzen. Ez dirudi arreta birdefinitzeko garai onena denik. Hala ere, gaur egungo egoerak, egoera larri ororen antzera, abantaila batzuk izan ditzake, edo gutxienez bizkortu egin dezake berriz pentsatu betebeharra baliabidean edo kolektiboan arreta jartzen duen ikuspegitik etxerik gabeko gizabanakoan oinarritutako beste ikuspegi baterako trantsizio hori. Metodoan eta arazoaren ikuspegi orokorrean oinarritutako hurbilketa albo batera utziko duen arreta; esku-hartze hurbilekoa, banakakoa eta espezializatua lehentasun izango dituena, eta erantzun malgua eta azkarra ardatz izango dituena. 


\section{Aipatutako bibliografia}

ANDERSON, I. (2010): "Services for homeless people in Europe: Supporting pathways out of homelessness", in EDGAR, B.; eta DOHERTY, B. (ed.), Homelessness Research in Europe, Brusela, FEANTSA.

APPELBAUM, R. P. (1990): “Counting the homeless”, in MOMENI, J. (ed.), Homelessnes in the United States: Data and Issues, New York, Praeger Press.

AVRANOV, D. (2002): "Figures on the extent of homelessness in the European Union revisited", Homelessness in Europe, 2002ko udaberria, 5-6 or. [〈http://bit.ly/12|CpVr〉].

- (1996): The Invisible Hand of the Housing Market. A Study on Effects of Changes in the Housing Market on Homelessness in the European Union, Brusela, FEANTSA.

- (ed.) (1998): Youth Homelessness in the European Union, Brusela, FEANTSA.

BAPTISTA, I. (2010): "Women and homelessness", in EDGAR, B.; eta DOHERTY, B. (ed.), Homelessness Research in Europe, Brusela, FEANTSA.

- (2009): "The drafting of the Portuguese Homeless Strategy: An insight into the process from a governance-oriented perspective", European Journal of Homelessness, 3. bol., 53-74. or.

BENJAMINSEN, L.; eta DYB, D. (2010): “Homelessness strategies and innovations", EDGAR, B.; eta DOHERTY, B. (ed.), Homelessness Research in Europe, Brusela, FEANTSA.

BILBOKO UDALA (2011): Informe técnico sobre la situación de las personas sin hogar y los recursos de ámbito municipal y foral, Bilbo, Bilboko Udala.

BOSCH, J. (2010): “Homelessnes among Migrants in Spain”, European Journal of Homelessnes, 4. bol. 139-154. or.
BROUSSE, C. (2004): The Production of Data on Homelessnes and Housing Deprivation in the European Union: Survey and Proposal, Brusela, Europako Batzordea.

BURT, M. (2001): Helping America's Homeless: Emergency Housing or Affordable Housing?, Washington, D. C., The Urban Institute.

BURT, M.; eta COHEN, B. (1989): "Diferences among homeless single women, women with children and single men", Social Problems, 36. bol., 508-524. or.

BUSCH-GEERTSEMA, V. (2010): "Defining and measuring homelessness", EDGAR, B.; eta DOHERTY, B. (ed.), Homelessness Research in Europe, Brusela, FEANTSA.

BYRNE, T. et al. (2012): "New perspectives on communitylevel determinants of homelessness", Journal of Urban Affairs, o bol., o zenb., 1-19. or.

CABRERA, P. J. (2009): Cómo avanzar en la medición y el seguimiento del sinhogarismo y la exclusión social en España [«http://www.trp.dundee.ac.uk/ research/.../NPP(Spanish)Final12.03.09.pdf)].

- (2007): “Exclusión residencial de los inmigrantes: entre la precariedad y la calle", SOS Racismo. Informe anual sobre el racismo en el Estado español 2007, Bartzelona, Icaria.

- (2006): Operación de recuento nocturno de las personas viviendo sin techo en las calles de Madrid [rhttp://www.enredpsh.org/IMG/pdf/ Resultados_recuento_dic2006.pdf >].

- (2004): Informe nacional de España 2004 para el Observatorio Europeo sobre Sinhogarismo, FEANTSA [/http://www.feantsa.es/IMG/pdf/ FEANTSA_2004_Informe_Espanol-2.pdf〉]. 
CABRERA, P. J.; eta MALGESINI, G. (2002): Inmigrantes y sinhogarismo. Informe Nacional 2001-2002, FEANTSA [<http://www.feantsa.es/IMG/pdf/ FEANTSA_2002_Informe_espanol_Migraciones. $p d f>]$

CABRERA, P. J.; RUBIO, M. J.; y BLASCO, J. (2008): ¿Quién duerme en la calle? Una investigación social y ciudadana sobre las personas sin techo, Bartzelona, Caixa Catalunya.

CÁRITAS (2012): VII Informe del Observatorio de la Realidad Social, Madril, Cáritas.

- (2009): La respuesta de Cáritas ante la crisis. Impacto, diagnóstico y propuestas, Madril, Cáritas [<http://www.uspceu.es/pdf/servicios/ caritasantelacrisis.pdf $>$.

COHEN, C. I. (1995): “Down and out in New York and London: A cross national comparison of homelessness", Hospital and Community Psychiatry, 45. bol, 769-776. or.

DAISKI, I. (2007): "Perspectives of homeless people on their health and health needs priorities", Journal of Advanced Nursing, 58. bol, 3. zenb., 273-281. or.

EDGAR, B. (2009): European Review of Statistics on Homelessness, Brusela, FEANTSA.

EDGAR, B.; eta DOHERTY, J. (ed.) (2010): Homelessness Research in Europe, Brusela, FEANTSA.

EDGAR, B.; eta MEERT, H. (2005): Fourth Review of Statistics on Homelessness in Europe. The ETHOS Definition of Homelessness, Brusela, FEANTSA.

EDGAR, B.; DOHERTY, J.; eta MEERT, H. (2004): Third Review of Statistics on Homelessness in Europe. Developing an Operational Definition of Homelessness, Brusela, FEANTSA.

- (2002): Review of Statistics on Homelessness in Europe, Brusela, FEANTSA.

ELISSEN, A. et al. (2013): “Improving homeless persons' utilisation of primary care: Lessons to be learned from an outreach programme in The Netherlands", International Journal of Social Welfare, 22. bol, 80-89. or.

ELLEN, G.; eta O'FLAHERTY, B. (2010): How to House the Homeless, New York, Russell Sage Foundation.

EUROPAKO BATZORDEA (2007): Measurement of Homelessness at European Union Level, European Communities, Brusela, Europako Batzordea [<http://ec.europa.eu/employment_ social/social_inclusion/docs/2007/study_ homelessness_en.pdf $>$ ].

EUROPAR BATASUNA (2012): “Dictamen del Comité Económico y Social Europoeo sobre el problema de las personas sin hogar", Diario Oficial de la Unión Europea, urtarrilak 28.

EUROPEAN OBSERVATORY ON HOMELESSNESS (2012): Counting Homeless People in the 2011 Housing and Population Census, Brusela, FEANTSA.

EUSTAT (2005): Encuesta sobre las personas sin hogar, Gasteiz, EUSTAT.

FEANTSA (2012a): FEANTSA Response to the National Reform Programmes 2012, Brusela, FEANTSA [<http:// www.feantsa.org/files/freshstart/Policy\%20 documents/nrp2012_feantsaresponse_ en.pdf>].
- (2012b): On the Way Home? FEANTSA Monitoring Report on Homelessness and Homeless Policies in Europe, Brusela, FEANTSA.

- (2011): Impact of Anti-crisis Austerity Measures on Homeless Services across the EU, Brusela, FEANTSA [<http://feantsa.horus.be/files/ freshstart/Policy\%2odocuments/Impact $\% 20$ of $\% 20$ Austerity $\% 20$ Measures $\% 200$ n $\% 20$ Homeless\%20Services_Policy\%2oPaper_ en.pdf>].

FIRDION, J.-M.; eta MARPSAT, M. (2007): “A research program on homelessness in France", Journal of Social Issues, 63. bol., 3. zenb,. 567-588. or.

FRAZER, H.; eta MARLIER, E. (2011): Social Impact of the Crisis and Developments in the Light of Fiscal Consolidation Measures, Brusela, Europako Batzordea [<http://ec.europa.eu/social/BlobSe rvlet?docld=8991\&langld=en〉].

FUNDACIÓN FOESSA (2012): Exclusión y desarrollo social. análisis y perspectivas. 2012, Madril, Fundación Foessa.

HOMBS, M. E. (2001): American Homelessness, Santa Barbara, ABC-CLIO.

HWANG, S. W. (2001): “Homelessness and health", Canadian Medical Association Journal, 164. bol., 1. zenb., 229-233. or. [<http://www. cmaj.ca/content/164/2/229>].

INE (2005): Encuesta sobre las personas sin hogar (EPSH 2005), Madril, Instituto Nacional de Estadística.

JASINSKI, J. et al. (2010): Hard Lives, Mean Streets: Violence in the Live of Homeless Women, Boston, Northeastern University Press.

JENCKS, C. (1994): The Homeless, Cambridge, Harvard University Press.

KOEGEL, P.; BURNAM, A.; eta MORTON, S. C. (1996): "Enumerating homeless people: Alternative strategies and their consequences", Evaluation Review, 20. bol., 378-403. or.

LAPARRA, M.; eta PÉREZ, B. (2010): El primer impacto de la crisis en la cohesión social de España, Madril, Fundación FOESSA.

MARKEE, P. (2009): New York City Homeless Shelter Population Reaches al-Time High (Briefing Paper), New York, Coalition for the Homeless [<http://coalhome.3cdn. net/64b7729eodo15dde1b_pym6b5zdp.pdf ].

MARS, A. (2012): “Grecia se echa a temblar”, El País, 2012-2-18 [<http://economia. elpais.com/economia/2012/02/18/ actualidad/1329597312_013324.html>].

MAYOCK, P.; SHERIDAN, S.; eta PARKER, S. (2012): “Migrant women and homelessness: The role of gender-based violence", European Journal of Homelessness, 6. bol., 1. zenb., 59-82. or.

MEANWELL, E. (2012): “Experiencing homelessness: A review of recent literature", Sociology Compass, 6. bol., 1. zenb., 72-85. or.

MEERT, H. et al. (2005): The Changing Profile of Homeless People: Still Depending on Emergencingservices in Europe: Who and Why?, Brusela, FEANTSA [<http://www.feantsa.es/IMG/pdf/ EN_WG2_Profiles_2005.pdf $)$. 
MORENO, G.; eta AIERDI, X. (2008): "Inmigración y servicios sociales: ¿última red o primer trampolín?”, Zerbitzuan, 44. zenb., 7-18. or. [khttp://www. zerbitzuan.net/documentos/zerbitzuan/ Inmigracion\%20y\%20servicios\%20sociales.pdf $)$ ].

MUÑOZ, M.; eta VÁZQUEZ, C. (1999): “Homeless in Spain: Psychological aspects", Psychology in Spain, 3. bol., 3-10. or.

MUÑOZ, M.; VÁZQUEZ, C.; eta CRUZADO, J. A. (1995): Personas sin hogar en Madrid. Informe psicosocial y epidemiológico, Madril, Madrilgo Erkidegoa.

MURPHY, K. (2011): “Rethinking homeless service provision in an economic recession", Brusela, FEANTSA [«http://www.feantsa.org/files/freshstart/ FEANTSA_Events/2011/springseminar/Murphy_ Presentation.pdf $>$ ].

O’CONELL, J. J. (2004): “Dying in the shadows: The challenge of providing health care for homeless people", Canadian Medical Association Journal, 170. bol., 8. zenb., 1.251-1.252. or.

O'SULLIVAN, E. (2010): “Welfare states and homelessnes", in EDGAR, B.; eta DOHERTY, B. (ed.), Homelessness Research in Europe, Brusela, FEANTSA.

PASSARO, J. (1996): The Unequal Homeless: Men on the Streets, Women in Their Place, New York, Routledge.

PHILIPPOT, P. et al. (2007): "Psychological research on homelessness in Western Europe: A review from 1979 to 2001", Journal of Social Issues, 63. bol., 3. zenb., 483-504. or.

PIPPERT, T. (2007): Road Dogs and Loners: Family Relationship among Homeless Men, Lanham, Lexington Books.

QUILGARS, D. (2010): “Youth homelessness”, EDGAR, B.; eta DOHERTY, B. (ed.), Homelessness Research in Europe, Brusela, FEANTSA.

RICO, P.; VEGA, L.; eta ARANGUREN, L. (1994): “Trastornos psiquiátricos en transeúntes: un estudio epidemiológico en Aranjuez (Madrid)", Revista de la Asociación Española de Neuropsiquiatría, 14. bol., 51. zenb., 633-649. or.

RODRÍGUEZ GARCÍA, A. (2008): Informe anual 2008 Estado español. Soluciones residenciales para personas sin-hogar, FEANTSA [rhttp:// www.feantsa.es/IMG/pdf/Informe_espanol_ vivienda_-_2008_ES.pdf〉].

ROSSI, P. H. (1989): Down and out in America: The Origins of Homelessness, Chicago, University of Chicago Press.

SHINN, M. (2007): “International homelessness: Policy, socio-cultural, and individual perspectives", Journal of Social Issues, 63. bol., 659-679. or.

SHINN, M. et al. (1998): "Predictors of entry into and exit from homelessness among families in New York
City", American Journal of Public Health, 88. bol., 1.651-1.657. or.

TOMPSETT, C. et al. (2003): "Homelessnes in the US and Germany: A cross-national analysis", Journal of Community \& Apllied Social Psycology, 13. bol., 240-253. or.

TORO, P. (2007): “Toward An International Understanding of Homelessness", Journal of Social Issues, 63. bol., 3. zenb., 461-481. or.

TORO, P.; DWORSKY, A.; eta FOWLER, P. J. (2007): “HomelesS youth in the United States: Recent research finding and intervention approaches", The 2007 National Symposium on Homelessness Research, Washington, D. C., U.S. Department of Housing and Urban Development; U.S. Department of Health and Human Services.

TORO, P. et al. (1999): “Obtaining representative samples of homeless persons: A two-city study", Journal of Community Pshychology, 27. bol., 2. zenb., 157-177. or.

UK LOCAL GOBERNMENT ASSOCIATION (2008): Survey of the Impact of the Economic Slowdown on Local Authorities, London, Local Government Association.

VÁZQUEZ, C. et al. (2003): "A comparative study of the 12-month prevalence of physical diseases among homeless people in Madrid (Spain) and Washington, D. C. (USA)", International Journal of Mental Health, 30. bol., 6-25. or.

VOSTANIS, P. et al. (2001): “Mental health problems and social supports among homeless mothers and children victims of domestic and community violence", International Journal of Social Psychiatry, 47. bol., 30-40. or.

WARNES, A.; eta CRANE, M. (2006): Factors in the Outcomes of the Resettlement of Homeless People. Unpublished Grant Proposal Approved for Funding, London, Economic and Social Research Council.

WILLIAMS, J. C. (2011): "Stand up and be counted: The politics of a homeless enumeration", Poverty \& Public Policy, 3. bol., 3. zenb., 1-27. orr.

WOLITSKI, R. J.; KIDDER, D. P.; eta FENTON, K. A. (2007): “HIV homelessness and public health: Critical issues and a call for increases action", AIDS and Behavior, 11. bol, 167-171. orr.

WRIGHT, N.; eta TOMPKINS, C. (2005): How Can Health Care Systems Effectively Deal with the Major Health Care Needs of Homeless People?, Geneva, Osasunaren Mundu Erakundea.

ZLOTNICK, C.; ROBERTSON, M. J.; eta LAHIFF, M. (1999): "Getting off the steets: Economic resources and residential exits among homeless adults", Journal of Community Psychology, 27. bol., 209-224. or. 